\title{
Review of the World Economic Outlook
}

Les Perspectives de l'économie mondiale du FMI (2018). Une analyse

\section{Daniela Magalhães Prates and Carolina Troncoso Baltar}

\section{(2) OpenEdition}

\section{Journals}

Electronic version

URL: http://journals.openedition.org/ei/6671

DOI: 10.4000/ei.6671

ISSN: 2553-1891

\section{Publisher}

Association Économie et Institutions

\section{Electronic reference}

Daniela Magalhães Prates and Carolina Troncoso Baltar, «Review of the World Economic Outlook », Économie et institutions [Online], 28 | 2020, Online since 18 June 2020, connection on 09 August 2020 URL : http://journals.openedition.org/ei/6671 ; DOI : https://doi.org/10.4000/ei.6671

This text was automatically generated on 9 August 2020

Revue Économie et institutions 


\title{
Review of the World Economic Outlook
}

\author{
Les Perspectives de l'économie mondiale du FMI (2018). Une analyse \\ Daniela Magalhães Prates and Carolina Troncoso Baltar
}

The authors would like to thank Jaime Marques Pereira for his valuable suggestions.

\section{Introduction}

1 The World Economic Outlook (WEO) is a survey by the IMF published twice a year (in April and October) and partly updated in January and July. The analysis and projections contained in the WEO, the IMF's flagship report, are integral parts of the IMF's surveillance of economic developments and policies in its member countries, of developments in international financial markets, and of the global economic system.

2 The four editions are coordinated by the Economic Counsellor and Director of the Research Department, a position currently held by economist Gita Gopinath, the first woman to hold that position. The survey of prospects and policies stems from a comprehensive interdepartmental review of world economic developments, which draws primarily on information the IMF staff gathers through its consultations with member countries. These consultations are notably carried out by the IMF's area departments-namely, the African Department, Asia and Pacific Department, European Department, Middle East and Central Asia Department, and Western Hemisphere Department-together with the Strategy, Policy, and Review Department; the Monetary and Capital Markets Department; and the Fiscal Affairs Department. Although the final edition of the WEO benefits from comments and suggestions by Executive Directors, the views expressed therein are those of the IMF staff and do not necessarily represent the views of the IMF's Executive Directors or their national authorities.

3 The two main editions have the same structure. The first chapter presents the IMF's outlook for the world economy in the short- and mid-term context, with projections out to four years. WEO forecasts include key macroeconomic indicators, such as GDP, 
inflation, current account and fiscal balance for more than 180 countries around the globe. The other three chapters are called 'analytical chapters'; these address major economic policy issues, in general related to the challenges facing the international economy and the policy recommendations to deal with them.

4 Yet, the analysis and prescriptions presented in the WEO are not necessarily translated into policy conditionalities imposed by the IMF in its rescue packages. As Prates and Farhi (2015) stress, this disconnection has become even greater since the global financial crisis (GFC), which had significant consequences for the IMF's macroeconomic theory and policy guidelines (Gallagher \& Ban, 2014).

In face of the failure of orthodox economics to provide a set of tools to avert the GFC, as well as to deal with the policy dilemmas in the post-crisis setting, the IMF's analytical and normative framework has encompassed issues that have been stressed by heterodox economists for a long time. Usually, those issues have already been taken over by unorthodox scholars of mainstream economics. ${ }^{1}$

Chronologically, the first one was the IMF's recognition of the need of including macroprudential aims in macroeconomic policies (Blanchard \& Dell'Ariccia, 2010; Blanchard, 2011). The second, third and fourth changes, respectively, were the more favourable view on capital controls (IMF, 2011 and 2012), ${ }^{2}$ the recognition of the negative effects of fiscal austerity in times of crisis (Blanchard \& Leigh, 2013), and the interconnectedness of global banks and the systemic risks posed by securitization (Basurto et al., 2015). The fifth one was the acknowledgement that instead of delivering economic growth, some neoliberal policies have increased inequality, jeopardizing sustained expansion (Ostry, Loungani \& Fourcery, 2016). ${ }^{3}$ It is also worth mentioning that the WEO of October 2019 stressed that the decline in long-term interest rates to historically very low or negative levels in advanced economies, while reducing the likely impact of further monetary policy easing, expands fiscal leeway. In this context, the IMF recommends that in countries where activity has weakened or could decelerate sharply, fiscal stimulus can be provided if fiscal space exists and fiscal policy is not already overly expansionary [...], especially where room to ease monetary policy is limited' (IMF, 2019, p. 24).

7 These critical analyses have been made through different types of documents or, as Longuet and Marques Pereira (2015) propose, different linguistic forms, such as staff discussion notes, policy papers, flagship reports ${ }^{4}$ and papers published in the IMF economic journal (Finance \& Development). The media impact and the potential audience for the IMF's new discourse is not independent of the type of linguistic form used. For instance, while a staff discussion note expresses the opinion of staff members, a flagships report (such as the WEO) conveys the IMF's official position.

In the next section, we present a critical review of the World Economic Outlook launched in April 2018. After summarizing the global outlook depicted in chapter 1, we focus on the three analytical chapters that dig into the determinants of long-term economic growth. Chapters 2 and 4 address two key issues for orthodox growth theory: labour force participation in advanced economies, and innovative activity and technological knowhow. Chapter 3, in turn, deals with a crucial issue to the heterodox approach to economic growth, i.e., the role of manufacturing in the dynamics of productivity, employment and income distribution. Yet, the chapter concludes that, as services can offer considerable scope for productivity gains, contributing to the convergence of income per worker across countries, the best policy response is not to 
overrule market forces and subsidize manufacturing. Another policy prescription of the analytical chapters is trade liberalization. Hence, once more, the IMF embraced the heterodox perspective only partially. As the WEO is a flagship report, this was more than expected.

\section{Beyond orthodoxy, but falling short of heterodoxy}

9 Chapter 1 of the WEO published in April 2018 depicts a positive short-term scenario, estimating global growth of 3.9 percent in 2018 and 2019. Then, the global economic recovery that began around mid-2016 has become broader and stronger, besides being above previous expectations. Faster growth in the euro area, Japan, and the United States (US) drove this output acceleration. All three of these economies grew above the expectations for 2017, along with some recovery in commodity exporters. The IMF revised upward the growth rates of several other emerging markets and developing economies in 2018, such as Mexico and emerging Europe.

10 Growing trade and investment continued as crucial factors driving the global upswing. A broad base and faster economic growth had not been seen since 2010, when the global economy recovered from the financial crisis. If the IMF staff's projections are confirmed, the three-year period 2017-2019 would record the largest and most stable expansion after such a crisis, but would still be lower than that observed in the precrisis boom. The synchronized expansion would help settle the remaining legacies of the crisis by accelerating the end of unconventional monetary policies in advanced economies, fostering investment, and improving labour markets.

11 As usual, chapter 1 also outlines the risks to the forecast. Although these are balanced over the next several quarters, over the medium and long term, the likelihood of negative shifts in the forecast rises. Two main risks are identified. The first risk refers to the possibility of monetary policy tightening sooner than expected in the US where demand is buoyant, stimulated by a more expansive fiscal policy. Accordingly, such tightening would have negative effects on highly indebted countries, firms, and households. However, the IMF does not explain why that contagion effect would take place.

The spillover of the monetary conditions in the US to other countries happens because the US dollar is the key currency, with its policy rate being the main interest rate of the current international monetary and financial system. It is worth noting that the crucial role of US monetary policy in shaping international financial conditions since the emergence of financial globalization, for a long time stressed by heterodox scholars, has already been recognized in mainstream economics (e.g., Rey, 2015) as well as by various IMF publications on the role of capital controls after the GFC (e.g., IMF, 2011a and 2011b).

13 The second risk concerns the increasing measures of trade restrictions and retaliation that could result in a trade war. Such a risk could intensify if the US trade deficit were to rise in a context of expansionist fiscal policy and no action in Europe and Asia to scale back surpluses. The renewed popularity of nationalistic policies, another collateral effect of the global financial crisis (GFC), has also fostered these measures. Pessimistic prospects for household income growth in advanced economies, coupled 
with trends of higher polarization in jobs and incomes, are also underlying such protectionist trend.

The IMF alerts that a trade war could jeopardize the multilateral rules-based trade system that took shape after World War II and that underpinned the unprecedented growth in the world economy. Hence, in this WEO (2018), the IMF explicitly supports trade liberalization, a key precondition for productive globalization, stressing its overall benefits for all groups of countries (advanced, emerging and developing, and low-income). Conversely, no explicit criticism of financial globalization, underlying the aforementioned contagion effect of US monetary policy, is presented. Finally, the chapter stresses that, if policymakers do not address the challenges for long-term growth, political risks could intensify, possibly reversing some of the progress that economic reforms and integration have achieved to date.

In face of such challenges, the analytical chapters (i.e., chapters 2, 3 and 4) focus precisely on the key determinants of long-term economic growth. These three chapters provide updated and interesting data, but there are important differences among them. Chapters 2 and 4 address two key issues for orthodox (i.e., neoclassical) growth theories: ${ }^{5}$ labour force participation in advanced economies, and innovative activity and technological knowhow, respectively. The conclusions and policy recommendations are also coherent with such theories.

Chapter 2 stresses that 'the availability of factors of production, including labor, is an important determinant of actual and potential growth in the long term. The participation rate, together with population growth, is the key determinant of labor supply'. Hence, population aging and, for many countries, declining overall participation rates could harm growth in advanced countries. It also argues that the widespread decline in participation of young and prime-age men is worrisome. The chapter recommends a set of policies to curb these effects, such as: tax policies (e.g., reforming the tax-benefit system by reducing the labour tax wedge) and educational investments (e.g., strengthening policies that improve the job-matching process that can encourage individuals to keep working or to seek employment). Moreover, the chapter criticizes the current trend of protectionism against labour mobility in the United States and Europe. It points out the role of migration in relieving the strain of population aging and in contributing to other long-term gains, such as higher growth and productivity, as already highlighted in chapter 4 of the WEO of October 2016.

Chapter 4 also makes a critique of protectionist policies regarding the mobility of goods and services. It stresses that measures to restrict trade and to benefit politicallyfavoured sectors of the economy will ultimately harm productivity growth. In the analysis of the process whereby innovative activity and technological knowhow spread across national borders, it is argued that 'globalization has intensified the diffusion of knowledge and technology across borders, helping to spread potential growth among countries and boost it at the global level' (p. 174). In other words, international trade and competition promote global knowledge diffusion and thus provide an important channel through which all countries can benefit from globalization. Therefore, 'from a policy perspective, greater global interconnectedness is thus key to maximizing inward technology diffusion and boosting economies' growth potential. But as economists have long emphasized, assimilating and productively using foreign knowledge often requires investments in domestic R\&D and in human capital, which enhance absorptive capacity' (p. 174). 

growth, especially for the Kaldorian theory of economic growth and distribution: the relationship between manufacturing output, on the one hand, and employment, productivity, economic growth and income distribution, on the other hand.

chapter begins by stating that the share of manufacturing jobs in overall employment is declining, a trend that has become 'a concern for policymakers and the broader public alike in both advanced economies and some developing economies' due to 'the widely held belief that manufacturing plays a unique role as a catalyst for productivity growth and income convergence and a source of well-paid jobs for lessskilled workers' (p. 147). Another worry is that currently poor countries may be trapped far from the global income frontier if they never pass through a developmental stage of substantial manufacturing employment.

21 Such believes and worries are grounded in many mainstream studies cited in the chapter. For instance, according to Baumol (1967), there is historical evidence that the growth of productivity and income tends to slow once factors of production begin to shift from manufacturing to services (Baumol, 1967; Imbs, 2016). Rodrik (2016) points out that such a phenomenon could be especially unsettling for developing economies, where employment shares are shifting from agriculture directly to services, as skipping a traditional industrialization phase could hinder the convergence process (i.e., their ability to narrow income gaps vis-à-vis advanced economies).

Against that backdrop, the aim of the chapter is to provide new evidence of the role of manufacturing in the dynamics of output per worker and in the level and distribution of labour earnings. It has two main findings.

23

Firstly, there is evidence that output has outpaced employment in the manufacturing sector in most countries since the early 1970s, reflecting comparatively fast productivity growth in the sector. However, the same pattern has not held at the global level. The broadly parallel movement of global manufacturing output and employment shares reflects a change in the country composition of global manufacturing employment in favour of developing economies, where output per worker tends to be lower.

24 Secondly, the rise in service share of employment simultaneously to the decline or stabilisation in the manufacturing share does not necessarily hinder economy-wide productivity growth. Such a rise has contributed positively to that growth in most developing economies. Indeed, some service industries have higher productivity levels and growth rates than manufacturing overall. Moreover, just as in manufacturing, productivity levels in services tend to converge to the global frontier (i.e., to the productivity level in the most productive countries). And, although labour earnings in manufacturing are somewhat higher and more uniformly distributed than in services, the main driver of the rise in labour income inequality in advanced economies since the 1980 s has been an increase in inequality within all sectors.

Therefore, as services can offer considerable scope for productivity gains, contributing to the convergence of income per worker across countries, according to the IMF the best policy response is not to overrule market forces and subsidize manufacturing. The goal of supporting equitable growth 'would be better served by policy efforts to raise productivity across all sectors and make the gains from higher productivity more inclusive. Facilitating the reallocation of labor to productively dynamic sectors, 
including by removing barriers to entry and trade in the service sector and supporting the reskilling of workers affected by structural change, is crucial to raise productivity and combat inequality' (p. 147).

Hence, chapter 4 broaches a very important issue that is the importance of manufacturing to a country's economic growth, productivity and income distribution. However, the chapter does not highlight Kaldor's seminal contribution, quoting that author only once. The analysis is based on non-neoclassical mainstream economists, such as Baumol (1967) and Rodrik (2016), who have included the issue in the analysis of economic growth, as had occurred with other heterodox subjects.

Kaldor (1967) formulates three propositions to explain the importance of manufacturing to GDP growth (McCombie \& Thirlwall, 1994). The first proposition affirms that the faster the rate of growth of manufacturing output, the faster the rate of growth of labour productivity in manufacturing, due to static and dynamic economies of scale or increasing returns to scale. This proposition is known in the literature as Verdoorn's Law. The second proposition affirms that there is a strong positive correlation between the manufacturing sector's growth rate and productivity growth outside the manufacturing sector, because the manufacturing sector produces goods that can be used by other sectors, thereby providing the possibility for improving their productivity. Finally, the last proposition asserts that the faster the rate of growth of the manufacturing sector, the faster the rate of GDP growth (Baltar, 2013).

Kaldor's (1967) propositions are still valid and important; however, to understand the role of manufacturing, it is crucial to consider the transformations that took place in global production, making the role of manufacturing more complex than before. The global strategies of transnational companies, with intense de-verticalization, fragmentation of activities, and a strong international outsourcing trend, affect each country's possibilities for industrial development (Hiratuka \& Sarti, 2017). This change created the possibility for developing countries to incorporate industrial activities in their production through their participation in different stages of the value chain (Baldwin, 2011). Yet, the incorporation of manufacturing activities is not necessarily related to higher possibilities of economic growth and development.

29 According to Hiratuka and Sarti (2017), large firms outsourced non-core business activities, including manufacturing activities, and at the same time they strengthened their intangible assets and increased their control over technology standards. The consequence has been stronger power of transnational companies and the value added created along the global value chain was concentrated mainly in developed countries (Chesnais, 1996; Hiratuka \& Sarti, 2017). This means that the possibilities for higher economic growth and development are related to the type of activities each country is able to produce and the value added they create. These activities can be manufacturing activities, services or even agricultural activities.

30 Moreover, the differentiation between manufacturing goods and services is more complex than before. According to Fornari et al. (2017), businesses have transferred many activities that used to belong to the manufacturing sector, such as accounting, advertising, food, etc., to suppliers to reduce costs. (encore, je suppose qu'il s'agit des entreprises qui ont fait ce transfert, c'est un peu vague) Then, it is necessary to qualify the discussion and better evaluate how services are related to industrial activities, because this relationship might have changed, impacting a country's economic growth 
differently. Along the same lines, Arbache (2015) emphasizes that, nowadays, goods and services are related in a way that makes it impossible to characterize them as a traditional manufactured good or as a conventional service. In the words of Fontagné and Harrison (2017): 'recent databases on trade in value added show that goods trade cannot easily be distinguished from services trade, and the more so for advanced economies' (p.5). In this sense, to analyse the importance of manufacturing and services to a country's economic activity became more complex just as manufactured goods and services are becoming more interrelated.

Thus, the types of goods and services a country can produce is crucial to its economic growth prospects. According to the Neo-Schumpeterian literature, the production of products that create higher possibilities for economic growth are those with technological content. Accordingly, the technological trajectories of different countries condition their possibilities of economic growth and development (Dosi, 1982). A country can enjoy a virtuous circle of economic growth if this economy is able to incorporate new products and processes of production that are close to the world technological frontier (Dosi, Tyson \& Zisman, 1989; Dosi, Pavitt \& Soete, 1990). In this sense, the possibilities for economic growth are related to a country's possibility to produce products in high demanded internationally, and the production of these goods are close to the world technological frontier.

Another important issue related to a country's productive structure and its possibilities for economic growth is the relationship between productive structure and the country's income inequality. Hartmann et al. (2017) stress that, 'the mix of products that an economy makes constrains the occupational choices, learning opportunities, and bargaining power of its workers and unions' (p. 75), therefore it has a very important role on the country's income distribution. According to the authors, technological catch-up and industrialization in many countries enabled these economies to create new jobs and learning opportunities for their workers, improving their income distribution; at the same time, the economies that passed through a deindustrialization and de-unionization process presented higher levels of income inequality.

In short, the Kaldorian and Neo-Schumpeterian literature emphasizes the importance of the type of activities and the specialization pattern of each country for their possibilities of economic growth, productivity and value added creation. Changes in the specialization pattern and in the potential economic growth may require government interference in the competitive process through a development strategy that includes industrial, technological, and trade policies.

This discussion questions the position highlighted in the WEO report on the importance of trade liberalization. On the contrary, this literature emphasizes the necessity to create activities that generate value added and, for that, the government might have to intervene in economic activity and in the country's international trade. Moreover, economies with a more diversified and integrated productive structure may have higher income levels and lower income inequality, while having higher economic growth potentialities. The possibilities of higher economic growth are fundamental to improving the country's income distribution, but they are not sufficient. Apart from that, state intervention is also crucial to the creation of the necessary institutions and policies in favour of a more equal distribution. 
Hence, in the WEO of April 2018, the IMF addresses another issue that is key to heterodoxy: the role of manufacturing in economic growth, employment, productivity and income distribution. As usual, the IMF embraced the heterodox perspective only partially. Yet, in this case, the linguistic form used-this publication conveys the IMF's official position-has had an important influence on the analysis and the policy recommendations of the analytical chapters.

\section{BIBLIOGRAPHY}

Arbache J., (2015), « Por que serviços? », in N. Barbosa, N. Marconi, M.C. Pinheiro, \& L. Carvalho (eds), Indústria e desenvolvimento produtivo no Brasil, São Paulo, Elsevier \& FGV.

Baldwin R., (2011), « Trade and Industrialisation after Globalisation's 2nd unbundling: How Building and Joining a Supply Chain are Different and why it Matters », NBER Working Papers, No. 11716. DOI: $10.3386 /$ w17716

Baltar C.T, (2013), « Economic Growth and Inflation in an Open Developing Economy: the Case of Brazil », PhD Thesis in Economy, University of Cambridge.

Basurto M.S., B. Jones, P. Lindner, P. \& J. Blankenheim, (2015), Securitization: The Road Ahead, IMF Staff Discussion Note, Washington, International Monetary Fund. URL: http://www.imf.org/ external/pubs/cat/longres.aspx?sk=42583

Baumol, W.J., (1967), « Macroeconomics of Unbalanced Growth: the anatomy of urban crisis », Amercian Economic Review, 57(3), p.415-26.

Blanchard O., (2011), « The Future of Macroeconomic Policy: Nine Tentative Conclusions ", IMFBlog, Washington, International Monetary Fund. URL: https://blogs.imf.org/2011/03/13/futureof-macroeconomic-policy

Blanchard O. \& D. Leigh, (2013), “Growth Forecast Errors and Fiscal Multipliers”, IMF Working Paper, No. 13/1, Washington, International Monetary Fund. URL: http://www.imf.org/external/ pubs/ft/wp/2013/wp1301.pdf

Blanchard O., G. Dell'Ariccia \& P. Mauro, (2010), Rethinking Macroeconomic Policy, IMF Staff Position Note, Washington, International Monetary Fund. URL: https://www.imf.org/external/ pubs/ft/spn/2010/spn1003.pdf

Chesnais F., (1996), A Mundialização do Capital, trad. Silvana Finzi Foá, São Paulo, Xamã Editora.

Colander D., R. Holt \& B. Rosser (Jr.), (2004), « The Changing Face of Mainstream Economics », Review of Political Economy, 16(4), p. 485-499.

Dequech D., (2007), « Neoclassical, Mainstream, Orthodox, and Heterodox Economics », Journal of Post Keynesian Economics, 30(2), p. 279-302.

Dosi G., (1982), « Technological Paradigms and Technological Trajectories: A Suggested Interpretation of the Determinants and Directions of Technical Change », Research Policy, 11(3), p. 147-162. 
Dosi G., K Pavitt \& L. Soete, (1990), The Economics of Technical Change and International Trade, Great Britain, Harvester Weatsheaf.

Dosi G., L. Tyson \& J. Zysman, (1989), « Trade, Technologies, and Development: A framework for discussing Japan ", in C. Johnson, L. Tyson, L. \& J. Zysman (eds), Politics and Productivity: How Japan's Development Strategy Works, New York, Harper Business.

Fontagné L. \& A. Harrison, (2017), « The Factory-Free Economy: Outsourcing, Servitization and the Future of Industry », NBER Working Paper Series, No. 23016. DOI: 10.3386/w23016

Fornari, V.C.B., R Gomes \& C Hiratuka, (2017), « Mudanças recentes nas relações intersetoriais: um exame das atividades de serviço e industriais », Revista Brasileira de Inovação, 16(1), p. 157-188. https://doi.org/10.20396/rbi.v16i1.8649143

Fritz B. \& D.M. Prates, (2014), « The New IMF Approach to Capital Account Management and its Blind Spots: Lessons from Brazil and South Korea ", International Review of Applied Economics, 28(2), p. $210-239$.

Gallagher K., (2012), "The IMF's New View on Financial Globalization: A Critical Assessment », Policy Issues in Brief, No. 026, Frederick S. Pardee Center for the Study of the Longer-Range Future, Boston University, « Policy Issues in Brief Series ». URL: https://open.bu.edu/handle/2144/22734 Gallagher K. \& C. Ban, (2014), « The IMF's perestroika moment », The Washington Post, edition of $12 / 17 / 2014$.

Hartmann D., M.R. Guevara, C. Jara-Figueroa, M.E Aristarán \& C.A. Hidalgo, (2017), « Linking Economic Complexity, Institutions and Income Inequality », World Development, vol. 93, p. 75-93.

Hiratuka C. \& F. Sarti, (2017), « Brazilian Industry: Recent Performance and Future Challenges », in P. Arestis, C. Baltar \& D.M. Prates (eds), The Brazilian economy since the Great Financial Crisis of 2007/2008, Cham, Switzerland, Palgrave Macmillan.

Imbs, J. (2016), « Structural change in the OECD: some facts », in L. Fontagné \& A. Harrison (eds), The factory-free economy: outsourcing, servitization, and the future of industry, Oxford, Oxford University Press.

IMF, (2011a), Recent Experiences in Managing Capital Inflows - Cross-Cutting Themes and Possible Policy Framework, Washington, International Monetary Fund. URL: http://bit.ly/ QSqrVQ

IMF, (2011b), The Multilateral Aspects of Policies Affecting Capital Flows, Washington, International Monetary Fund. URL: http://bit.ly/SRk4lr

IMF, (2012), The Liberalization and Management of Capital Flows: An Institutional View, Washington, International Monetary Fund. URL: https://www.imf.org/external/np/pp/eng/ 2012/111412.pdf

IMF, (2016), World Economy Outlook, October 2016, Washington, International Monetary Fund. IMF, (2018), World Economy Outlook, April 2018, Washington, International Monetary Fund. IMF, (2019), World Economy Outlook, October 2019, Washington, International Monetary Fund. Jones C.I., (1998), Introduction to economic growth, New York \& London, W.W Norton \& Company. Kaldor N., (1967), Strategic Factors in Economic Development, Ithaca (NY), New York State School of industrial and labor relations, Cornell University, « The Frank W. Pierce memorial lectures series ». 
Longuet S. \& J. Marques Pereira, (2015), « Discours de la crise, crise du discours », Économie et institutions, $\mathrm{n}^{\circ}$ 22, p. 7-34 ; [En ligne]. URL : http://journals.openedition.org/ei/971

Longuet S. \& J. Marques Pereira, (2019), «L'analyse du discours économique du point de vue de l'économie. Analyse de l'argumentation et de la réception de l'article de trois économistes du Fonds monétaire international (FMI) », Langage et société, 166(1), p. 97-116.

McCombie J. \& A. Thirlwall, (1994), Economic Growth and the Balance-of-Payments Constraint, London, Palgrave Macmillan UK.

Ostry J.D, P. Loungani \& D. Furce, (2016), « Neoliberalism: Oversold? », Finance \& Development, June 2016, 53(2), p. 38-41. URL: https://www.imf.org/external/pubs/ft/fandd/2016/06/pdf/ostry.pdf

Prates D.M \& M. Farhi, (2015), « From IMF to the Troika: new analytical framework, same conditionalities ", Économie et institutions [Online], $n^{\circ}$ 23. URL: http://journals.openedition.org/ei/ $\underline{5680}$

Rey, H. (2015), « Dilemma not Trilemma: The Global Financial Cycle and Monetary Policy Independence », NBER Working Paper No. 21162, May. URL: https://www.nber.org/papers/w21162

Rodrik, D. (2016), « Premature Deindustrialization », Journal of Economic Growth, 21, p. 1-33.

\section{NOTES}

1. We adopt the concepts of mainstream, orthodoxy and heterodoxy proposed by Colander, Holt and Rosser (2004), according to which mainstream economics is a sociologically defined category, consisisting of the ideas held by the elite of the profession, i.e., those individuals who are dominant in the leading academic institutions, organizations, and journals at any given time, especially the top graduate schools. It represents a broader and more eclectic approach to economics than the orthodoxy of the profession that is an intellectual defined category, referring to the most recent dominant "school of thought", currently "neoclassical economics". Finally, the term "heterodoxy" has both an intellectual and a sociological aspect. Heterodox schilars do not subscribe to the orthodox school of thought and are highly unlikely to get funding through normal channels. Moreover, even when they share with mainstream economists similar views about the limitations of the orthodoxy, they refuse to work within the of mainstream framework because either nature of the modelling process or the assumptions made.

2. For a critical assessment of the new IMF approach on capital controls, see Fritz and Prates (2014) and Gallagher (2012).

3. Longuet and Marques Pereira (2019) analyse this paper on the basis of the approach called political economy of discourse.

4. Besides the WEO, the IMF's other flagship report is the Global Financial Stability report, published twice a year (April and October).

5. On the neoclassical growth theories, see Jones (1998). 


\section{ABSTRACTS}

The paper presents a critical review of the World Economic Outlook, the flagship report of the International Monetary Fund (IMF), launched in April 2018. After summarizing the global outlook depicted in chapter 1 , we focus on the three analytical chapters that dig into the determinants of long-term economic growth. Although the report recognizes the role of manufacturing in the dynamics of productivity, employment and income distribution stressed by the heterodox growth theory, it concludes that services can offer considerable scope for productivity gains, contributing to the convergence of income per worker across countries. In face of this diagnostic, the report argues that neither subsidize manufacturing nor step back on trade liberalization are the best policies responses to support equitable growth. Hence, once more, the IMF embraced the heterodox perspective only partially.

Cet article présente un examen critique de l'édition d'avril 2018 du rapport «Perspective de l'économie mondiale» du Fonds monétaire international (FMI). Après un résumé des perspectives mondiales décrites dans le chapitre 1, nous nous concentrons sur les trois chapitres analytiques qui examinent les déterminants de la croissance économique à long terme. Bien que le rapport reconnaisse le rôle du secteur manufacturier dans la dynamique de la productivité, de l'emploi et de la distribution des revenus tel que la théorie hétérodoxe de la croissance, il conclut que les services peuvent offrir des possibilités considérables de gains de productivité, tout en contribuant à la convergence du revenu par travailleur entre les pays. Face à ce diagnostic, le rapport soutient que les subventions accordées à l'industrie manufacturière et le recul de la libéralisation du commerce ne sont pas les meilleures réponses politiques pour soutenir une croissance équitable. Dès lors, et une fois de plus, le FMI n'aura-t-il adopté que partiellement la perspective hétérodoxe.

\section{INDEX}

Keywords: International Monetary Fund, World Economic Outlook, Growth Theory, multilateral trade

Mots-clés: Fonds monétaire international, perspectives de l'économie mondiale, théorie de la croissance, commerce multilatéral

\section{AUTHORS}

\section{DANIELA MAGALHÃES PRATES}

Senior Economic Affairs Officer at the United Nations Conference on Trade and Development (UNCTAD); Associate professor (on leave) at the Institute of Economics of the University of Campinas (IE/UNICAMP, Brazil).

\section{CAROLINA TRONCOSO BALTAR}

Lecturer at IE/UNICAMP, Brazil and Editor-in-chief of the Brazilian journal Economia e Sociedade 